\title{
Toward strong science to support equitable water sharing in securitized transboundary watersheds
}

\author{
Michael L. Wine ${ }^{1,2}$ (DD \\ Received: 17 April 2019 / Accepted: 22 July 2019 / Published online: 5 August 2019 \\ (C) Plant Science and Biodiversity Centre, Slovak Academy of Sciences 2019
}

\begin{abstract}
With unprecedented water scarcity in Earth's water-limited regions, due in large part to continued rapid population growth, peaceable relations among nations are threatened as nations compete with one another for increasingly scarce water resources. This competition occurs against the backdrop of global change - an array of multi-disciplinary socioeconomic and physical processes that affect water availability. In transboundary basins this multitude of complex uncertain processes often underlain by numerous non-linear, coupled mechanisms controls the amount of water available to be shared among basin riparians and aquatic ecoystems. In this context equitable water sharing and knowledge-based management of besieged aquatic ecosystems demands the strongest possible scientific inference. While transboundary water sharing under non-stationarity has been treated, the impacts of securitization on hydrological process understanding remain largely unknown. However, it is precisely this hydrological process understanding that controls water available for sharing in securitized transboundary basins under non-stationarity. Given the expense involved in solving problems of water scarcity amidst rising population, securitizing state actors may perceive benefit in influencing the hydrologic science literature, including by climatizing increased water scarcity or reduced water quality, even if the true impact is that of a riparian's own water management practices. Indeed, evidence is already emerging of differing hydrologic process understanding in studies impacted by securitization versus those in the broader international literature. Modifying treaties and water sharing agreements to give a neutral third-party arbiter responsibility for resolving contested hydrologic science issues may promote equitable science for the benefit of both aquatic ecosystems and co-riparian states.
\end{abstract}

Keywords Global change $\cdot$ Jordan River $\cdot$ Sea of galilee $\cdot$ Securitization $\cdot$ Transboundary $\cdot$ Water scarcity

\section{Background}

With four billion people facing severe water scarcity (Mekonnen and Hoekstra 2016), food production is limited, ecosystem functioning impaired, and urban water supply stressed in Earth's water-limited regions (Jury and Vaux 2007). Unresolved, this unprecedented water scarcity portends water-driven conflicts (Shuval 1992; Wolf 2009; Stetter et al. 2011; Zeitoun et al. 2019) and degradation of treasured aquatic ecosystems (Wine 2019d). Resolving water conflicts is largely treated as a political issue - the determination of equitable allocations (Benvenisti and Gvirtzman 1993;

Michael L. Wine

mlw63@ cornell.edu

1 Geomorphology and Fluvial Research Group, Ben Gurion University of the Negev, Beer Sheva, Israel

2 Denver, USA
Wolf 1999). However, in the Anthropocene ${ }^{1}$ (Lewis and Maslin 2015) water science plays the role of quantifying water

\footnotetext{
${ }^{1}$ The term Anthropocene has become synonymous with securitization. Firstly, a key characteristic of the Anthropocene is that the measures that humans have put in place to secure their populations in turn threaten human security. For example, construction of dams simultaneously secures populations by providing water for municipal uses and agriculture, while threatening the security of aquatic populations and downstream riparians. If human security is in turn linked to national security, then securitization occurs. Secondly, the defining of a new geological epoch may be seen as risking exaggeration of human impacts. Nonetheless, the range of human impacts in recent decades is unprecedented as seen from the extensive desiccation of the Aral Sea, Lake Urmia, the Great Salt Lake, and the Dead Sea, among many other examples. Moreover, climatic non-stationarity requires new methods be employed for predictive modeling. The term Anthropocene then is used here to refer to the unprecedented environmental degradation of recent decades along with the particular modeling challenges that earth scientists face in attempting to disentangle highly correlated processes, account for large state changes, model impacts of climate change, and predict impacts of rising human population. It is the author's belief that earth (and allied) scientists have a responsibility to produce credible investigations of Anthropocene problems - that support rational discourse, are balanced, clearly quantify the uncertainties around conclusions, and involve appropriate contributions from all relevant disciplines.
} 
availability and how it will change over the coming decades due to diverse global change drivers, a profoundly interdisciplinary challenge (Brasseur and Van Der Pluijm 2013; Wine and Davison 2019) involving - at minimum - surface water, groundwater, environmental, climate, ecological, social, and economic science (Liu et al. 2017).

If the extent of the interdisciplinary challenge were inadequate, politicization and securitization of water resources - including through climatization (Grant et al. 2015) - magnifies the challenge when vested interests, concerned with economic or security aspects of water, endeavor to sway the scientific literature to their benefit (Wine 2019a, b, c, d). Securitization of water resources occurs when "an issue is presented as an existential threat, thereby allowing for the endorsement of exceptional measures to deal with the identified threat" (Zeitoun and Warner 2006; Warner and Boas 2017). One consequence of securitization is the adoption of a sanctioned discourse (Feitelson 2002) in which the securitizing actor sanctions a certain set of ideas it considers favorable and advances this sanctioned discourse while stealthily, but vigorously suppressing alternative perspectives. While it is the duty of the hydrologic science community to ensure high quality and free science - characterized by open dialogue and willingness to refute assumptions and theories - in all realms including securitized transboundary watersheds, the securitized domain poses unique and formidable challenges to scientists seeking the truth (Wine 2019d).

\section{Hydrology securitized}

Challenges facing scientists in securitized transboundary watersheds may include:

- Limited freedom of expression (Wine 2019c).

- Attempts to co-opt the hydrologic literature to game water sharing (Wine 2019b) or limit government responsibility for degradation of treasured aquatic ecosystems (Wine 2019d).

- Limited data access (Klein 1998; Avni et al. 2015; Momblanch et al. 2019) to scientists who stray from sanctioned discourse (Wine 2019d).

Therefore, we aim to expose some of the (geo)political consequences of global change processes unique to the securitized transboundary watershed setting.

\section{Lake Kinneret as an exemplar}

As an exemplar of works that have potential implications in the securitized transboundary water context, we take all studies that focus on Lake Kinneret, Israel and the Upper Jordan River (UJR) watershed since 2007 whose lead authors' domicile acts to securitize the watershed and in which the study's conclusions have the effect of modifying long-term water availability or quality (Givati and Rosenfeld 2007, 2009, 2013; Tal 2017, 2018; Givati et al. 2019; Gophen 2019; Tal 2019b, c), with potential consequences for downstream riparians including the Kingdom of Jordan and the Palestinian Authority. With respect to the theses and key premises of these studies, we ask:

- What are the water-sharing consequences of each claim and implications with regard to attribution of unprecedented degradation of aquatic ecosystems?

- Are the conclusions in keeping with the broader international literature (Table 1)?

- Is the support provided for each claim adequate to ensure with reasonable confidence that the results will be a solid basis for equitable water sharing and knowledge-based management of aquatic ecosystems, understanding that human populations and aquatic ecosystems within the watershed are experiencing severe water scarcity?

- Finally, where applicable, what strategies could be adopted to strengthen scientific inference?

While this exercise focuses in particular on the securitized transboundary watershed context, it is applicable more broadly to strong inference (Platt 1964) in the global change hydrology discipline as well as to other securitized or politicized science topics.

\section{Hydrologic science and water sharing}

\section{Climatic changes}

In the Mediterranean region changing climatic conditions are predicted in the form of higher temperatures and decreasing precipitation (Giorgi and Lionello 2008). In a water-sharing context, decreasing inflows implies decreasing available water subject to water sharing agreements. If the proportion of water allocated to each riparian remains the same, then decreasing available water implies a corresponding reduction in the responsibility of the upstream riparian to supply water to downstream riparians or secure aquatic ecosystems. Indeed, numerous publications maintain that impacts of climate change are already the primary driver of changes in Lake Kinneret's water balance (Givati and Rosenfeld 2007, 2009, 2013; Tal 2017, 2018; Givati et al. 2019; Gophen 2019; Tal 2019a, b, c).

Specific processes nominally supporting the claim of climatically driven decreasing water availability include 
Table 1 Under non-stationarity hydrologic changes are anticipated

\begin{tabular}{|c|c|}
\hline Driver & Sanctioned discourse \\
\hline $\begin{array}{l}\text { Suppression of } \\
\text { orographic } \\
\text { precipitation }\end{array}$ & $\begin{array}{l}\text { "The loss of available water of about } 110 \text { million } \mathrm{m}^{3} \mathrm{yr}^{-1} \\
\text { (about } 6.5 \% \text { of the national water consumption in Israel) is } \\
\text { shown to be caused by a decreasing trend in the factor of } \\
\text { precipitation enhancement [in the Golan heights] by } \\
\text { uplifting on topographic barriers" (Givati and Rosenfeld } \\
\text { 2007) } \\
\text { "this comment further enhances the confidence that } \\
\text { orographic precipitation has been suppressed over Israel" } \\
\text { (Givati and Rosenfeld 2009) } \\
\text { - This perspective implies that Lake Kinneret may be Earth's } \\
\text { only lake shrinking primarily due to orographic precipitation } \\
\text { suppression due to anthropogenic aerosols. }\end{array}$ \\
\hline $\begin{array}{l}\text { Decreasing available } \\
\text { water }\end{array}$ & $\begin{array}{l}\text { "decreasing trend in the incoming fresh water into the Sea of } \\
\text { Galilee (Lake Kinneret) during the recent decades" (Givati } \\
\text { and Rosenfeld 2013; Tal 2017, 2018; Givati et al. 2019; Tal } \\
\text { 2019a, b, c) }\end{array}$ \\
\hline
\end{tabular}

Non-securitized perspective

- "The rainfall analysis [which excludes the Golan Heights] shows no evidence of any suppression of rainfall over the mountains due to pollution" (Alpert et al. 2008)

- "No decrease in the ratio between the mountain precipitation to that over the coastal region was found" (Halfon et al. 2009)

- In the Dead Sea, whose basin completely includes that of Lake Kinneret "substantial human intervention in the lake watershed caused a steep decline of lake level" (Morin et al. 2018)

- "over-exploitation" (Inbar and Bruins 2004)

- "no decreasing trends in inflow from the headwaters of the Upper Jordan River" and "statistically stable median precipitation" (Wine et al. 2019b)

- "no significant temporal change of the annual rainfall occurred in any region of the study area", which excluded the Golan Heights (Halfon et al. 2009)

- "drier conditions ... not yet statistically evident in surface station rain data" (Shohami et al. 2011)

Climate change

- "effects of the predicted climate changes on the hydrological "predicted results varied between the climate models" cycle in the region shows an increase in potential (Rimmer et al. 2011) evaporation and a decrease in streamflow volumes in the Jordan River" (Givati et al. 2019)

- "climate model projections of regional precipitation remain highly uncertain" (Black et al. 2010)

- "Measurements over the past forty years in the watershed. .. • questions have been raised about the credibility of climate strongly support the view that it is in fact climate change, and projections given that they are poorly correlated with the associated reduced rainfall, that is responsible for the observations in the historical record (Nohara et al. 2006; Lake Kinneret's reduced inflow" (Tal 2019c)

Douglass et al. 2008; Koutsoyiannis et al. 2009; Kundzewicz et al. 2009a; b; Anagnostopoulos et al. 2010; Christy et al. 2010; Koutsoyiannis et al. 2010; Kundzewicz and Stakhiv 2010; Schwartz et al. 2010; Stockwell 2010; Scafetta 2012, 2013; Legates 2014; Connolly et al. 2019).

"Water loss" •enhancement of gravitating water loss"

- "There is no black hole swallowing water in the Hula Valley" (Wine 2019c)

Water quality

- "steady increase in salinity levels in the lake which as present hydrological models predict, corresponds to the reduction in precipitation" (Tal 2019b)

- "the increasing rates of freshwater consumption and diversion in Lake Kinneret's headwaters clearly contribute to the observed water quality degradation" (Wine 2019a)

- "the trends of salinity according to other models were mild" (Rimmer et al. 2011)

Evaporation

- "it is clear that due to increase in temperature. .. evaporation

- "Claims that evaporation from Lake Kinneret have increased has increased over the past decades." (Tal 2019b) due to rising temperatures neglect the shrinkage of the lake's area - the area over which evaporation occurs" (Wine 2019a)

- "During July - August the daily temperature of the air and water surface were $2-4{ }^{\circ} \mathrm{C}$ higher, the daily wind over the lake was $\sim 80 \%$ weaker, and the evaporation from the lake was $\sim 5 \%$ lower than the long-term July - August mean." (Shilo et al. 2015)

Groundwater-surface • "Artesian wells... in fact, release water into the watershed and water interactions do not constitute a net drain on lake inflow" (Tal 2019b)

"current hydrologic theory suggests the hydraulic head gradient driving artesian flows in northern Israel within the Kinneret's basin is derived from Mount Hermon such that increasing release of water from artesian wells reduces natural spring flows" (Wine 2019a)

- "An interaction between the lake and the groundwater storage is clearly seen from the analysis to conclude that groundwater has a potential to recharge the lake" (Vaheddoost and Aksoy 2018) 
Table 1 (continued)

\begin{tabular}{|c|c|c|}
\hline Driver & Sanctioned discourse & Non-securitized perspective \\
\hline $\begin{array}{l}\text { Agricultural water } \\
\text { consumption }\end{array}$ & • "Allocations to farmers have been cut back" (Tal 2019b) & $\begin{array}{l}\text { "the decrease in discharge of the Upper Jordan River } \\
\text { corresponded to a period of expanding irrigated agriculture" } \\
\text { (Wine et al. 2019b) }\end{array}$ \\
\hline Prevailing views & $\begin{array}{l}\text { "The prevailing view among Israeli government experts and } \\
\text { academic water researchers is that diminishing rainfall along } \\
\text { with increased evaporation have reduced annual flow into } \\
\text { the lake." (Tal 2019b) }\end{array}$ & $\begin{array}{l}\text { - "this 'prevailing view' is the only sanctioned view. They } \\
\text { further neglect to articulate the consequences faced should a } \\
\text { scientist resist adopting sanctioned discourse" (Wine 2019a) }\end{array}$ \\
\hline
\end{tabular}

Untangling climatic impacts for knowledge-based management of transboundary water resources is challenged by conflicting perspectives between state-sanctioned discourse and non-securitized perspectives. The state sanctioned discourse focuses on attributing causes of observed long-term water balance and water quality changes in Lake Kinneret and its watershed to exogenous (often climatic) factors. This sanctioned discourse derives from scientists whose domicile also serves as an upstream riparian and actor securitizing the Jordan River headwaters. The non-securitized perspective comes from scientists domiciled in a state that protects freedom of expression, refers to a non-securitized domain that is likely to be influenced by a similar set of hydrologic processes, or references works published before 2005 - since which time securitization of the hydrologic literature appears to have intensified

orographic precipitation suppression by anthropogenic aerosols (Givati and Rosenfeld 2007, 2009), shifts in the Arctic Oscillation (Givati and Rosenfeld 2013), and anthropogenic climate change (Givati et al. 2019; Gophen 2019; Tal 2019b, c). However, these claims of climatic change impacts on the water balance of the Kinneret have been widely questioned (Inbar and Bruins 2004; Alpert et al. 2008; Morin et al. 2018; Wine 2019b, c, d; Wine et al. 2019b) and are at odds with the international literature, which notes the role of increasing human water consumption in desiccating lakes on many of Earth's continents (Micklin 1988; Micklin 2007; Aghakouchak et al. 2015; Moore 2016; Fazel et al. 2017; Wurtsbaugh et al. 2017; Alborzi et al. 2018; Chaudhari et al. 2018; Rodell et al. 2018; Wang et al. 2018a; Khazaei et al. 2019; Shentsis et al. 2019; Wine et al. 2019a).

In transboundary watersheds that include substantial consumption of water by water dependent systems, such as evaporation from lakes, the parties might reasonably agree that this consumption reduces the amount of water available for human consumption by the same amount - with the aim of preserving such ecosystems. Here too climate change plays a role with quantitative predictions of evaporation increasing substantially from Earth's lakes (Wang et al. 2018b) and Lake Kinneret (Rimmer et al. 2011) due to climate warming - 16\% and 10$20 \%$, respectively, by the end of the century. In fact, temperature increases are not the only variable relevant to changing open water evaporation - changing lake area (Zhan et al. 2019) and wind associated with synoptic weather patterns (Shilo et al. 2015) complicate this relationship. However, these quantitative physically based predictions contrast with qualitative attributions suggesting - despite decreases in lake area - that "it is clear that due to increase in temperature, evaporation has increased over the past decades" (Tal $2019 b$ ). Thus, according to this attribution, substantial reductions of available water have definitively already occurred and justify reducing allocations to downstream water users, whereas the quantitative literature not only indicates a more complex reality but also offsets the largest changes in lake evaporation flux by eight decades from the present.

\section{Groundwater-surface water interactions}

Groundwater-surface water interactions also affect water sharing and aquatic ecosystems in a transboundary watershed. If groundwater and surface water are isolated from one another and do not interact - a pre-Theis (1935) conceptual model then presumably the upstream riparian may consume groundwater according to her discretion within her territory as such groundwater consumption has no bearing on the renewable surface waters governed by the water sharing agreement. In contrast, if groundwater does interact with surface water then reductions in surface flows - due to rising rates of groundwater consumption - should have no impact on the amount of water shared with downstream riparians. Indeed, the sanctioned discourse of Lake Kinneret states that "Artesian wells, in fact, release water into the watershed and do not constitute a net drain on lake inflow" (Tal 2019b). This groundwater originates "from an aquifer which never contributed to Kinneret flow historically" (Tal 2019b). Thus, the sanctioned discourse of securitized Lake Kinneret's watershed advocates for the discredited pre-Theis (1935) conceptual model that would simultaneously allow the upstream riparian to increase groundwater consumption while reducing her obligation to share surface waters - whose availability decreases as a consequence of groundwater extraction - and minimizing her responsibility for any degradation of aquatic ecosystems.

\section{Agricultural water consumption}

In contrast to the growing trend of basing agricultural water consumption on repeatable and verifiable methods of remote sensing, which show clear increases in agricultural areas in recent decades (Wine et al. 2019b), the sanctioned discourse of the UJR watershed favors an opposing view: "discussions 
with water managers responsible for the region confirm that ... water removal from the Kinneret watershed has been further reduced: Allocations to farmers have been cut back; Fish ponds, for example, which used to consume significant quantities of water, have essentially been phased out of operation" (Tal 2019b). This sanctioned discourse, in contrast to Landsat imagery, also furthers the narrative that the JRH watershed, within one of Earth's more densely populated countries, is essentially pristine and is on a trajectory toward becoming more pristine. It would follow logically that from such a pristine setting, decreasing streamflow must be a result of natural or exogenous processes, outside the control of the upstream riparian, and therefore a reflection of decreasing available water, and a decreasing responsibility of the upstream riparian to share water with downstream riparians or secure aquatic ecosystems.

\section{Prevailing views}

Given the complexity of the Earth system, the concept of a consensus is powerful and increasingly used in the climate change literature to convey the strength of agreement among scientists regarding the anthropogenic origin of observed climate change (Oreskes 2004; Doran and Zimmerman 2009; Cook et al. 2013; Maibach et al. 2014). The power of the concept of a consensus on climate change is derived only in part from the widespread view of climate scientists, who have studied a range of alternative hypotheses and now advance rising greenhouse gas concentrations as the driver of observed warming trends. A paramount condition of the power assigned to consensus is the freedom of expression amongst the scientists.

Tal (2019b) suggests a similar consensus regarding the role of climate change in modifying the water balance of the UJR watershed: "The prevailing view among Israeli government experts and academic water researchers is that diminishing rainfall along with increased evaporation have reduced annual flow into the lake. The dramatic drop in average annual precipitation in the watershed is typically attributed to climate change". Indeed a cursory look at the literature would appear to support this assertion (Givati and Rosenfeld 2007, 2009, 2013; Givati et al. 2019; Gophen 2019; Tal 2019b, c).

However, a deeper examination of "prevailing views" among water scientists in Israel questions the premise of Tal (2019b) that water scientists domiciled in Israel have freedom of expression. Reporters Without Borders (https://rsf.org/en/ ranking\#) ranks Israel 87 a rank that reflects its policy of censorship. According to the US State Department, this censorship includes "specific military issues as well as strategic infrastructure issues such as oil and water supplies" (https://www.state.gov/j/drl/rls/hrrpt/2006/78854.htm). Wine (2019b) confirms that "securitization is a euphemistic term that belies the treatment of scientists - by the securitizing actor
- whose research departs from sanctioned discourse." Moreover, "in a securitized context, the securitizing entity also serves as a scientific puppetmaster, guiding sanctioned discourse toward publication, and discouraging unsanctioned discourse through the use of all possible means. Consequently, science and securitization are fundamentally at odds in securitized basins" (Wine 2019c). Thus, the claim of prevailing views or consensus is weakened in a securitized context or one in which freedom of expression is stifled.

\section{Shortcomings in the Lake Kinneret literature}

Of the studies claiming climatic factors are the primary driver of observed decreasing inflows to Lake Kinneret, numerous shortcomings arise, weakening their potential to serve as a basis for equitable management of a transboundary basin or knowledge-based management of aquatic ecosystems (Fig. 1). Limitations include:

- None consider multiple quantitative lines of reasoning that have been or could be verified by international scientists (i.e., remote sensing or measurements by independent third parties).

- All originate from a securitized domain where freedom of expression is limited (Wine 2019a, b, c).

- Reliance on qualitative "expert opinion" may be used to arrive at quantitative conclusions, thereby weakening their objectivity and reproducibility (Wine 2019a).

- The science of groundwater-surface water interactions predates Theis (1935), part of a broader trend of disparity between the science adopted within the securitized zone versus that present in the broader international literature (Wine 2019a).

- Methodology may be absent or difficult to reproduce, challenging verification or falsification of theses (Wine 2019a).

- Data that are inconsistent with the objective of sanctioned discourse are consistently disregarded (Wine 2019a).

- Data access may be limited to trusted individuals known to produce sanctioned discourse alone (Wine 2019d; Wine et al. 2019b).

- Lack of model validation or selection of optimal model structure on the basis of objective quantitative criteria.

- Ubiquitous disagreement between the sanctioned discourse assigning Lake Kinneret's shrinkage to climatic factors versus opposing conclusions reached in the broader literature (Table 1).

These shortcomings prevent certain studies within the scientific literature from serving as a reliable means by which to quantify changes in water availability, and in so doing 


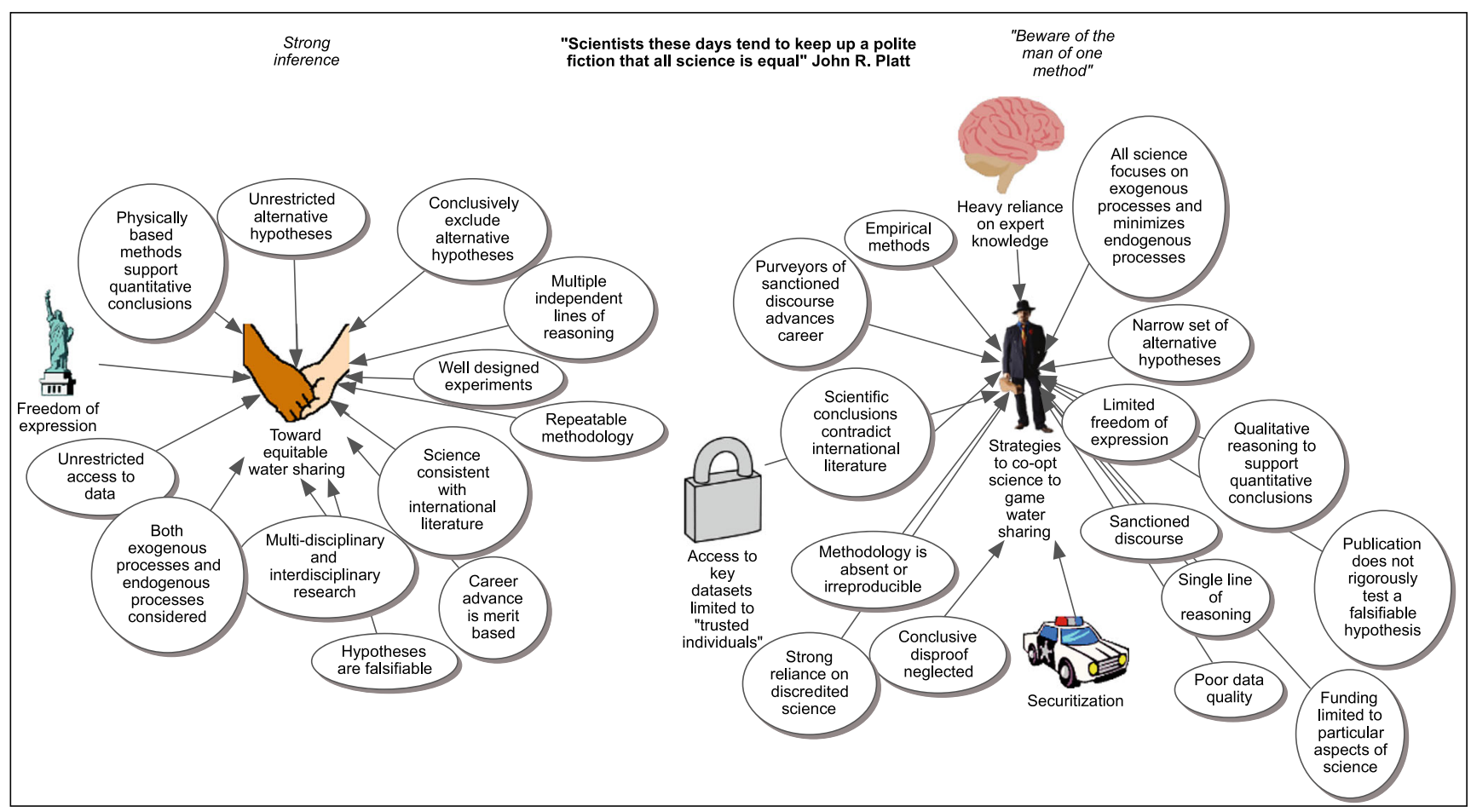

Fig. 1 Centuries of scientific process have provided a basis for methods of strong inference to facilitate equitable water sharing. We suggest this as template to determine if particular studies or bodies of literature are conducive to the strong inference necessary for equitable water sharing and knowledge-based management of besieged aquatic ecosystems determine how water allocations to aquatic ecosystems and riparians of a transboundary basin should change over time due to global change drivers.

\section{Toward a physical hydrology basis for equitable water sharing}

Given the extent of the international hydrologic global change literature, what are the objective characteristics of individual studies or bodies of literature that provide the strong scientific basis necessary for equitable water sharing in a transboundary basin and knowledge-based management of aquatic ecosystems forced by global change drivers? Here we propose criteria by which the broader hydrologic literature might be filtered to ensure that science that modifies water sharing in a water-scarce transboundary watershed does so on the basis of strong inference (Platt 1964). Such literature:

- Arises from a non-securitized domain with strong protections for freedom of expression. "Intellectual progress is compatible only with perfect freedom in the conduct of investigation and in the announcement both of results and of conclusions based upon those results. Attention is called also to the fact that the scientific world can place no reliance upon reports of research carried on under conditions which limit its freedom by an enforced agreement with any preconceived views or dogmas" (American Society of Naturalists 1937). (While there is no index of scientific freedom, a possible surrogate may be the Freedom in the World Index. Scholars at Risk also documents certain incidents of insults against academic freedom.) The role of members of the international community whose freedom of expression is protected - in desecuritizing hydrologic science - is also advanced by Momblanch et al. (2019): "transboundary research projects should be promoted by independent international institutions" that are not influenced by securitizing state actors. However, through case by case review of studies emerging from the securitized domain, valid and sound scientific studies may be found that can serve as a basis for equitable water sharing in the transboundary context.

- The methodology is clearly stated and repeatable, aimed at testing and conclusively excluding alternative hypotheses. It is based on data that are readily available and have been subjected to stringent quality control, whose methods are known and documented in the lingua franca of science.

- Processes in the body of literature are weighted according to their scientific importance and are funded and investigated irrespective of whether they lead to increase, 
decrease, or no change in water sharing obligations of the upstream riparian or the responsibility of the upstream riparian for the condition of aquatic ecosystems. Given the breadth of global change processes this will involve both multi- and inter-disciplinary research.

- Quantitative conclusions are supported by a physically based methodology based on the modern state of the international scientific literature.

- Conclusions are premised on multiple lines of independent reasoning and based on data sources that are either undisputed by any riparian, independently verifiable by all parties (i.e., remote sensing), or measured by an independent third party unaffiliated with any securitizing actor.

By filtering studies that can impact transboundary water sharing and treasured aquatic ecosystems through the filter suggested here, not only can water sharing and management become more equitable, but the quality of the scientific literature in such domains may improve. Such a goal might be achieved by modifying existing water sharing agreements to state explicitly what attributes a hydrologic study must have such that it can be considered sufficiently compelling to modify a water sharing agreement. Moreover, the riparians might reasonably agree to resolve disagreements regarding the state of hydrologic science on the basis of hydrologic science measurements (including remote sensing) and determinations made by a neutral third party. Such an agreement might prevent jockeying in the hydrologic science literature to influence water sharing, neutralize power dynamics, disincentivize securitization, and thereby promote a strong hydrologic science underpinning that would favor equitable water sharing in transboundary watersheds under non-stationarity.

Acknowledgements I wish to acknowledge funding from the United States-Israel Educational Foundation - the Fulbright Commission in Israel. The author was supported by a post-doctoral fellowship from the Kreitman School of Advanced Graduate Studies, the Ben Gurion University of the Negev. The constructive comments of two anonymous reviewers were greatly appreciated.

\section{Compliance with ethical standards}

Conflict of interest The authors declare no conflict of interest. The funders had no role in the design of the study; in the collection, analyses, or interpretation of data; in the writing of the manuscript, or in the decision to publish the results.

\section{Glossary}

Climatization overemphasis of climatic factors relative to the demonstrated quantitative impacts of other anthropogenic drivers in eliciting an observed state
Riparian a state entitled to water rights in a particular watershed as a consequence of the intersection of its boundaries with those of that watershed

Sanctioned In a context where freedom of speech is not discourse protected, the domain of views with respect to a securitized issue considered acceptable by the securitizing actor, typically an authoritarian state.

Securitization a transition away from rational discourse and normative democratic principles in response to a threat deemed to necessitate such extraordinary measures.

\section{References}

Aghakouchak A, Norouzi H, Madani K, Mirchi A, Azarderakhsh M, Nazemi A, Nasrollahi N, Farahmand A, Mehran A, Hasanzadeh E (2015) Aral Sea syndrome desiccates Lake Urmia: call for action. J Great Lakes Res 41:307-311. https://doi.org/10.1016/j.jglr.2014.12. 007

Alborzi A, Mirchi A, Moftakhari H, Mallakpour I, Alian S, Nazemi A, Hassanzadeh E, Mazdiyasni O, Ashraf S, Madani K, Norouzi H, Azarderakhsh M, Mehran A, Sadegh M, Castelletti A, Aghakouchak A (2018) Climate-informed environmental inflows to revive a drying lake facing meteorological and anthropogenic droughts. Environ Res Lett 13. https://doi.org/10.1088/1748-9326/ aad246

Alpert P, Halfon N, Levin Z (2008) Does air pollution really suppress precipitation in Israel? J Appl Meteorol Climatol 47:933-943. https://doi.org/10.1175/2007jamc1803.1

American Society of Naturalists (1937) Scientific freedom. Nature 139: 185-185. https://doi.org/10.1038/139185b0

Anagnostopoulos GG, Koutsoyiannis D, Christofides A, Efstratiadis A, Mamassis N (2010) A comparison of local and aggregated climate model outputs with observed data. Hydrol Sci J 55:1094-1110. https://doi.org/10.1080/02626667.2010.513518

Avni N, Fishbain B, Shamir U (2015) Water consumption patterns as a basis for water demand modeling. Water Resour Res 51:8165-8181. https://doi.org/10.1002/2014wr016662

Benvenisti E, Gvirtzman H (1993) Harnessing international-law to determine Israeli-Palestinian water rights - the mountain aquifer. Nat Resour J 33:543-567

Black E, Brayshaw DJ, Rambeau CMC (2010) Past, present and future precipitation in the Middle East: insights from models and observations. Philos Trans R Soc A Math Phys Eng Sci 368:5173-5184. https://doi.org/10.1098/rsta.2010.0199

Brasseur GP, Van Der Pluijm B (2013) Earth's future: navigating the science of the Anthropocene. Earth's Future 1:1-2. https://doi.org/ 10.1002/2013ef000221

Chaudhari S, Felfelani F, Shin S, Pokhrel Y (2018) Climate and anthropogenic contributions to the desiccation of the second largest saline lake in the twentieth century. J Hydrol 560:342-353. https://doi.org/ 10.1016/j.jhydrol.2018.03.034

Christy JR, Herman B, Pielke R, Klotzbach P, Mcnider RT, Hnilo JJ, Spencer RW, Chase T, Douglass D (2010) What do observational datasets say about modeled tropospheric temperature trends since 1979? Remote Sens 2:2148-2169. https://doi.org/10.3390/ rs2092148 
Connolly R, Connolly M, Soon W, Legates DR, Cionco RG, Herrera VMV (2019) Northern hemisphere snow-cover trends (19672018): a comparison between climate models and observations. Geosciences 9. https://doi.org/10.3390/geosciences9030135

Cook J, Nuccitelli D, Green SA, Richardson M, Winkler B, Painting R, Way R, Jacobs P, Skuce A (2013) Quantifying the consensus on anthropogenic global warming in the scientific literature. Environ Res Lett 8. https://doi.org/10.1088/1748-9326/8/2/024024

Doran PT, Zimmerman MK (2009) Examining the scientific consensus on climate change. EOS Trans Am Geophys Union 90:22-23. https://doi.org/10.1029/2009EO030002

Douglass DH, Christy JR, Pearson BD, Singer SF (2008) A comparison of tropical temperature trends with model predictions. Int J Climatol 28:1693-1701. https://doi.org/10.1002/joc. 1651

Fazel N, Haghighi AT, Klove B (2017) Analysis of land use and climate change impacts by comparing river flow records for headwaters and lowland reaches. Glob Planet Chang 158:47-56. https://doi.org/10. 1016/j.gloplacha.2017.09.014

Feitelson E (2002) Implications of shifts in the Israeli water discourse for Israeli-Palestinian water negotiations. Polit Geogr 21:293-318. https://doi.org/10.1016/S0962-6298(01)00038-5

Giorgi F, Lionello P (2008) Climate change projections for the Mediterranean region. Glob Planet Chang 63:90-104. https://doi. org/10.1016/j.gloplacha.2007.09.005

Givati A, Rosenfeld D (2007) Possible impacts of anthropogenic aerosols on water resources of the Jordan river and the sea of Galilee. Water Resour Res 43. https://doi.org/10.1029/2006wr005771

Givati A, Rosenfeld D (2009) Comments on "does air pollution really suppress precipitation in Israel?". J Appl Meteorol Climatol 48: 1733-1750. https://doi.org/10.1175/2009jamc1902.1

Givati A, Rosenfeld D (2013) The Arctic oscillation, climate change and the effects on precipitation in Israel. Atmos Res 132:114-124. https://doi.org/10.1016/j.atmosres.2013.05.001

Givati A, Thirel G, Rosenfeld D, Paz D (2019) Climate change impacts on streamflow at the upper Jordan river based on an ensemble of regional climate models. J Hydrol Reg Stud 21:92-109. https://doi. org/10.1016/j.ejrh.2018.12.004

Gophen M (2019) Climate change and water loss in the Kinneret drainage basin. Land Use Policy 80:424-429. https://doi.org/10.1016/j. landusepol.2018.03.008

Grant S, Tamason CC, Jensen PKM (2015) Climatization: a critical perspective of framing disasters as climate change events. Clim Risk Manag 10:27-34. https://doi.org/10.1016/j.crm.2015.09.003

Halfon N, Levin Z, Alpert P (2009) Temporal rainfall fluctuations in Israel and their possible link to urban and air pollution effects. Environ Res Lett 4. https://doi.org/10.1088/1748-9326/4/2/025001

Inbar M, Bruins HJ (2004) Environmental impact of multi-annual drought in the Jordan Kinneret watershed, Israel. Land Degrad Dev 15:243-256. https://doi.org/10.1002/ldr.612

Jury WA, Vaux HJ 2007. The emerging global water crisis: Managing scarcity and conflict between water users. In: Advances in agronomy, (eds). Academic Press: 1-76

Khazaei B, Khatami S, Alemohammad SH, Rashidi L, Wu C, Madani K, Kalantari Z, Destouni G, Aghakouchak A (2019) Climatic or regionally induced by humans? Tracing hydro-climatic and land-use changes to better understand the Lake Urmia tragedy. J Hydrol 569:203-217. https://doi.org/10.1016/j.jhydrol.2018.12.004

Klein M (1998) Water balance of the upper Jordan river basin. Water Int 23:244-248. https://doi.org/10.1080/02508069808686778

Koutsoyiannis D, Montanari A, Lins HF, Cohn TA (2009) Climate, hydrology and freshwater: towards an interactive incorporation of hydrological experience into climate research. Hydrol Sci J 54:394 405. https://doi.org/10.1623/hysj.54.2.394

Koutsoyiannis D, Efstratiadis A, Mamassis N, Christofides A (2010) On the credibility of climate predictions. Hydrol Sci J 53:671-684. https://doi.org/10.1623/hysj.53.4.671
Kundzewicz ZW, Stakhiv EZ (2010) Are climate models "ready for prime time" in water resources management applications, or is more research needed? Hydrol Sci J 55:1085-1089. https://doi.org/10.1080/ 02626667.2010 .513211

Kundzewicz ZW, Mata LJ, Arnell NW, Döll P, Jimenez B, Miller K, Oki T, Şen Z (2009a) Water and climate projections. Hydrol Sci J 54: 406-415. https://doi.org/10.1623/hysj.54.2.406

Kundzewicz ZW, Mata LJ, Arnell NW, Döll P, Jimenez B, Miller K, Oki T, Șen Z, Shiklomanov I (2009b) The implications of projected climate change for freshwater resources and their management. Hydrol Sci J 53:3-10. https://doi.org/10.1623/hysj.53.1.3

Legates DR (2014) Climate models and their simulation of precipitation. Energy Environ 25:1163-1175. https://doi.org/10.1260/0958-305X. 25.6-7.1163

Lewis SL, Maslin MA (2015) Defining the Anthropocene. Nature 519: 171-180. https://doi.org/10.1038/nature14258

Liu J, Yang H, Gosling SN, Kummu M, Flörke M, Pfister S, Hanasaki N, Wada Y, Zhang X, Zheng C, Alcamo J, Oki T (2017) Water scarcity assessments in the past, present, and future. Earth's Future 5:545559. https://doi.org/10.1002/2016ef000518

Maibach E, Myers T, Leiserowitz A (2014) Climate scientists need to set the record straight: there is a scientific consensus that human-caused climate change is happening. Earth's Future 2:295-298. https://doi. org/10.1002/2013ef000226

Mekonnen MM, Hoekstra AY (2016) Four billion people facing severe water scarcity. Sci Adv 2

Micklin PP (1988) Desiccation of the Aral Sea - a water management disaster in the Soviet-Union. Science 241:1170-1175. https://doi. org/10.1126/science. 241.4870 .1170

Micklin P (2007) The Aral Sea disaster. In: Annual review of earth and planetary sciences, (eds). 47-72

Momblanch A, Holman IP, Jain SK (2019) Current practice and recommendations for modelling global change impacts on water resource in the himalayas. Water 11. https://doi.org/10.3390/w11061303

Moore JN (2016) Recent desiccation of western Great Basin saline lakes: lessons from Lake Abert, Oregon, U.S.a. Sci Total Environ 554-555: 142-154. https://doi.org/10.1016/j.scitotenv.2016.02.161

Morin E, Ryb T, Gavrieli I, Enzel Y (2018) Mean, variance, and trends of Levant precipitation over the past 4500 years from reconstructed Dead Sea levels and stochastic modeling. Quat Res 91:751-767. https://doi.org/10.1017/qua.2018.98

Nohara D, Kitoh A, Hosaka M, Oki T (2006) Impact of climate change on river discharge projected by multimodel ensemble. J Hydrometeorol 7:1076-1089. https://doi.org/10.1175/JHM531.1

Oreskes N (2004) The scientific consensus on climate change. Science 306:1686. https://doi.org/10.1126/science.1103618

Platt JR (1964) Strong inference. Science 146:347. https://doi.org/10. 1126/science.146.3642.347

Rimmer A, Givati A, Samuels R, Alpert P (2011) Using ensemble of climate models to evaluate future water and solutes budgets in Lake Kinneret. Israel J Hydrol 410:248-259. https://doi.org/10. 1016/j.jhydrol.2011.09.025

Rodell M, Famiglietti JS, Wiese DN, Reager JT, Beaudoing HK, Landerer FW, Lo MH (2018) Emerging trends in global freshwater availability. Nature 557:651-659. https://doi.org/10.1038/s41586018-0123-1

Scafetta N (2012) Testing an astronomically based decadal-scale empirical harmonic climate model versus the ipcc (2007) general circulation climate models. J Atmos Sol Terr Phys 80:124-137. https://doi. org/10.1016/j.jastp.2011.12.005

Scafetta N (2013) Discussion on climate oscillations: Cmip5 general circulation models versus a semi-empirical harmonic model based on astronomical cycles. Earth-Sci Rev 126:321-357. https://doi.org/10. 1016/j.earscirev.2013.08.008 
Schwartz SE, Charlson RJ, Kahn RA, Ogren JA, Rodhe H (2010) Why hasn't earth warmed as much as expected? J Clim 23:2453-2464. https://doi.org/10.1175/2009jcli3461.1

Shentsis I, Inbar N, Rosenthal E, Magri F (2019) Assessing water consumption and aquifer discharge through springs based on the joint use of rain and flow data in the yarmouk river basin. Environ Earth Sci:78. https://doi.org/10.1007/s12665-019-8359-0

Shilo E, Ziv B, Shamir E, Rimmer A (2015) Evaporation from Lake Kinneret, Israel, during hot summer days. J Hydrol 528:264-275. https://doi.org/10.1016/j.jhydrol.2015.06.042

Shohami D, Dayan U, Morin E (2011) Warming and drying of the eastern Mediterranean: additional evidence from trend analysis. J Geophys Res-Atmos 116. https://doi.org/10.1029/2011jd016004

Shuval HI (1992) Approaches to resolving the water conflicts between Israel and her neighbors - a regional water-for-peace plan. Water Int 17:133-143

Stetter S, Herschinger E, Teichler T, Albert M (2011) Conflicts about water: securitizations in a global context. Coop Confl 46:441-459. https://doi.org/10.1177/0010836711422462

Stockwell DRB (2010) Critique of drought models in the Australian drought exceptional circumstances report (decr). Energy Environ 21:425-436. https://doi.org/10.1260/0958-305x.21.5.425

Tal A (2017) Will demography defeat river rehabilitation efforts? The case of the river Jordan. Water Res 111:404-419. https://doi.org/ 10.1016/j.watres.2016.11.047

Tal A (2018) Addressing desalination's carbon footprint: the Israeli experience. Water 10. https://doi.org/10.3390/w10020197

Tal A (2019a) Climate change's impact on Lake Kinneret: letting the data tell the story. Sci Total Environ. https://doi.org/10.1016/j.scitotenv. 2019.05.282

Tal A (2019b) The implications of climate change driven depletion of Lake Kinneret water levels: the compelling case for climate changetriggered precipitation impact on Lake Kinneret's low water levels. Sci Total Environ 664:1045-1051. https://doi.org/10.1016/j. scitotenv.2019.02.106

Tal A (2019c) Letter to the editor regarding Wine et al. (2019): Lake Kinneret and climate change. Sci Total Environ 664:175-176. https://doi.org/10.1016/j.scitotenv.2019.01.371

Theis CV (1935) The relation between the lowering of the piezometric surface and the rate and duration of discharge of a well using ground-water storage. EOS Trans Am Geophys Union 16:519524. https://doi.org/10.1029/TR016i002p00519

Vaheddoost B, Aksoy H (2018) Interaction of groundwater with Lake Urmia in Iran. Hydrol Process 32:3283-3295. https://doi.org/10. 1002/hyp.13263

Wang J, Song C, Reager JT, Yao F, Famiglietti JS, Sheng Y, Macdonald GM, Brun F, Schmied HM, Marston RA, Wada Y (2018a) Recent global decline in endorheic basin water storages. Nat Geosci 11: 926-932. https://doi.org/10.1038/s41561-018-0265-7

Wang W, Lee X, Xiao W, Liu S, Schultz N, Wang Y, Zhang M, Zhao L (2018b) Global lake evaporation accelerated by changes in surface energy allocation in a warmer climate. Nat Geosci 11:410-414. https://doi.org/10.1038/s41561-018-0114-8

Warner J, Boas I (2017) Securitisation of climate change: the risk of exaggeration. Ambiente \& Sociedade 20:203-224

Wine ML (2019a) Letter to editor re Tal (2019): Climaticization of environmental degradation - an Anthropocene epoch response to failure of governance. Sci Total Environ. https://doi.org/10.1016/j. scitotenv.2019.04.343

Wine ML (2019b) Response to comment on "agriculture, diversions, and drought shrinking Galilee Sea”. Sci Total Environ 663:436-437. https://doi.org/10.1016/j.scitotenv.2019.01.372

Wine ML (2019c) There is no black hole swallowing water in the Hula valley. Land Use Policy 84:363-364. https://doi.org/10.1016/j. landusepol.2019.02.046

Wine ML (2019d) Under non-stationarity securitization contributes to uncertainty and tragedy of the commons. J Hydrol 568:716-721. https://doi.org/10.1016/j.jhydrol.2018.11.044

Wine ML, Davison JH (2019) Untangling global change impacts on hydrological processes: resisting climatization. Hydrol Process 33: 2148-2155. https://doi.org/10.1002/hyp.13483

Wine LM, Null ES, Derose JR, Wurtsbaugh AW (2019a) Climatizationnegligent attribution of great salt Lake desiccation: a comment on Meng (2019). Climate 7. https://doi.org/10.3390/cli7050067

Wine ML, Rimmer A, Laronne JB (2019b) Agriculture, diversions, and drought shrinking Galilee Sea. Sci Total Environ 651:70-83. https:// doi.org/10.1016/j.scitotenv.2018.09.058

Wolf AT (1999) Criteria for equitable allocations: the heart of international water conflict. Nat Resour Forum 23:3-30. https://doi.org/10. 1111/j.1477-8947.1999.tb00235.x

Wolf AT (2009) A long term view of water and international security. J Contemp Water Res Educ 142:67-75. https://doi.org/10.1111/j. 1936-704X.2009.00056.x

Wurtsbaugh WA, Miller C, Null SE, Derose RJ, Wilcock P, Hahnenberger M, Howe F, Moore J (2017) Decline of the world's saline lakes. Nat Geosci 10:816-821. https://doi.org/10.1038/ ngeo3052

Zeitoun M, Warner J (2006) Hydro-hegemony - a framework for analysis of trans-boundary water conflicts. Water Policy 8:435-460. https:// doi.org/10.2166/wp.2006.054

Zeitoun M, Mirumachi N, Warner J, Kirkegaard M, Cascão A (2019) Analysis for water conflict transformation. Water Int:1-20. https:// doi.org/10.1080/02508060.2019.1607479

Zhan S, Song C, Wang J, Sheng Y, Quan J (2019) A global assessment of terrestrial evapotranspiration increase due to surface water area change. Earth's Future. https://doi.org/10.1029/2018ef001066

Publisher's note Springer Nature remains neutral with regard to jurisdictional claims in published maps and institutional affiliations. 